\title{
The relationship between of international migration, income per capita and unemployment rate in Indonesia
}

\author{
Siti Komariyah ${ }^{1 *}$, R. Alamsyah Sutantio ${ }^{2}$ \\ 1) Faculty of Economics and Business, Universitas Jember, Indonesia \\ 2) Politeknik Negeri Jember, Indonesia \\ *To whom correspondence should be addressed.Email: sitikomariyah.feb@unej.ac.id

\begin{tabular}{|l|l|l|l|l|}
\hline DOI: & Received: & Revised: & Accepted: & Published: \\
\hline
\end{tabular} \\ \begin{tabular}{|l|l|l|l|l|}
\hline 10.22437/ppd.v8i4.9863 & 05.07 .2020 & 03.11 .2020 & 04.11 .2020 & 07.11 .2020
\end{tabular}
}

\begin{abstract}
International migration has become an interesting issue in recent decades as globalization has become increasingly widespread as a form of openness in the world economy. This economic openness also results in changes in life socially, economically and culturally more dynamically. One of the dynamics of socio-economic conditions is shown by the increasingly flexible and dynamic international migration that occurs in several countries. Some underlying factors include conditions of income and unemployment. This study aims to analyse the response of migration when there is dynamics in per capita income as a proxy for welfare and unemployment as a proxy for employment conditions. VAR analysis is a method to see these responses through the IRF. The results of the analysis showed a significant response from migration as a result of the shock that occurred in both variables and with OLS estimation, both of these variables have a significant impact on influencing Indonesia's international migration flow. These is a signal that the main factor causing international migration is dominant due to the dynamics of income and labour market conditions (unemployment) in Indonesia. Although in other cases, migration also has a positive impact on some parties such as increasing income per capita for migrants, reducing unemployment and increasing the country's foreign exchange, but this condition also needs proper supervision and management. This must also be considered from various other aspects such as demographic conditions related to the age structure of the population and availability of employment to create a balance in the labour market.
\end{abstract}

Keywords: Income per capita, International migration, Unemployment

JEL Classification: F22, F62, F63

\section{INTRODUCTION}

International migration has become an interesting socio-economic issue to discuss due to its complexity which takes role in various fields of study such as social, economy, and law. A country shall pay attention to the migration flow since this will greatly impact the socio-economic condition of the home country either in terms of 
emigration or immigration. The increasing international migration is also considered as a development effort as explained in the World Migration Report (IOM-UN, 2018) held in Marrakesh, Morocco which was attended by 164 countries including Indonesia (Timorria, 2018). This condition indicates that international migration does not only impact the country's development, but also increases international cooperation. The migrant contributes to the development. This is reflected from the remittance which is proven to help increasing family welfare and the country's foreign exchange (Timorria, 2018). The migration flow could significantly decrease the unemployment or raise the income per capita either at the home country or destination country.

International migration could also happen due to the push and pull perspective which means the migration flow is caused by push and pull factors. The push factor is usually coming from the home country while the pull factor comes from the destination country (Zimmerman, 1996). The migration flow correlates to the dynamics of unemployment rate and income per capita. This has gained a special attention especially from the European countries (Ramirez et al., 2014).

The same issue in Indonesia needs to be discussed thoroughly since the migration flow is the result of intense global economy integration. Hence, the dynamics of unemployment and per capita income can be responded by the migration flow rate in Indonesia. In the past 25 years, the migration rate in Indonesia stated as deficit. This was shown in 1992 where the net migration number obtained from World Bank was 35.412 people and in 2017 it became -494.777. It indicates that emigration level is greater than the immigration. It means there are more people emigrate than those immigrate. This shall be highlighted since this phenomenon is caused by various factors. One of them is the economic factor which generally has a great influence.

Several empirical studies such as Mihi-Ramirez \& Kumpikaite (2013); Ramirez, et al., (2014) and Vojtovich (2013) implied that economy integration becomes the main factor of the international migration. In the other hand, social factor could also be a trigger though it has smaller contribution than the economic factor. The variation of income and unemployment become the push and pull factors. Besides, based on the research of Monseny (2014), location-based policy integration conducted in the region of Southern Spain and Andalusia provided probability in terms of migration which was based on the territory limitations. Meanwhile, the empirical study of Latif (2015) highlighted the unemployment factor caused by permanent migration in Canada by using analysis and panel data. The analysis result showed that immigration will have a positive impact for the unemployment rate in the short-term. However, in the long-term, it will cause a negative but insignificant impact to the unemployment rate.

In this phenomenon, the Neo Classic approach was used to explain the rise of unemployment rate and the low income level at the home country which cause emigration (Martinoia, 2011) from the home country perspective. In the other hand, emigration has a positive impact on unemployment and welfare level which was reflected from the income per capita at the home country. Immigration will tend to happen at the countries with lower level of unemployment which attract the immigrant to work there (Heid \& Larch, 2011). Later, those economic factors attract and trigger the migration flow (Cushing \& Poot, 2004). Those things above also trigger the pressure and desire to migrate from their home country which has a low income rate to other countries with higher income rate (Cattaneo, 2008). 
An effective factor to stimulate growth of international migration flow is the economic factor since the global economy integration will be the main factor in raising the dynamics (Ramirez et al., 2014). Emigration will tend to happen at the countries with low income and employment level while immigration will happen to the countries with higher level of income and employment that those attract the immigrant. This reflects human's effort to improve their life and their welfare through income.

However, international migration flow will also bring several impacts for both home country and destination country. The immigration effect on the unemployment in the destination country will depend on the probability and the available number of labor. In the other hand, immigrant will bring a positive impact to the destination country since they will increase the demand on goods and service consumed by the immigrant. Besides, it will also influence the production amount as the result of the immigrants' performance.

Meanwhile, for the home country, emigration brings positive impact by increasing remittance as the result of the emigrants' income which in the end it will raise the family welfare. Besides, emigration could decrease the unemployment rate at the home country. Thus, if the migration flow was handled well, it will bring positive impacts for both countries and improving international cooperation to achieve internal and external welfare. Based on the explanation above, this study will highlight the response among variables such as migration flow, unemployment rate and income per capita when facing dynamics each other, as well as observing the effect of socio-economic factors, which consist of unemployment rate and income per capita, on the migration flow in Indonesia.

\section{METHODS}

This study uses secondary data in the form of annual data (time series) obtained from World Bank. Based on the objective above, this study uses VAR (Vector Autoregressive) analysis method to see the responses among variables as well as observing the effect of unemployment rate variable and income per capita on migration flow. To see the response, this study uses IRF (Impulse Response Function) to see the response among periods. Meanwhile, the effect of unemployment rate and income per capita on the migration flow could be seen at the probability value on the Ordinary Least Square (OLS) estimation. In VAR estimation, there are several pre-estimation tests such as data stationarity test, co-integration test, optimum lag test, IRF test, and Variance Decomposition (VD) test. After that, VAR estimation will be applied.

Several testing stages above have their own objective based on each test function. First, the unit root test. This test is used to see the data stationarity. At the time series data and a stochastic process, the data is considered as stationary if the median and variant are constant along the time series and the co-variance value between two periods depends on lag. Then, the co-integration test is to see whether there is a longterm or short-term relationship within the model through Johansen test by comparing the statistics trace and critical value. The first co-integration concept was introduced by Engle and Granger (1987). Next, the optimum lag test is to determine the optimum lag through AIC (Akaike Information Criteria) test. Then, IRF test is to see the responses showed by each variable when there is a shock happens at the other variables.

This study adopted the model from Ramirez et al. (2014) and Latif (2015) that 
the OLS estimation model is simulated as follows:

Net_Migrasi ${ }_{t}=\alpha_{1}+\beta_{1}$ Unemployment_rate $_{t}+\beta_{2}$ GDP $/$ Cap $_{t}+\varepsilon_{t}$

Net_migrasi is the proxy of migration flow that reflects the data of immigration number subtracted by emigration with 'people' as the data unit. Unemployment rate is amount of unemployment with data unit ' $\%$ ' and GDP/Cap reflects income per capita with 'rupiah' as the unit. Meanwhile, $\alpha$ and $\beta$ are coefficients and t is time series data and $\varepsilon$ is error term.

Later, the model will be transformed into VAR estimation model as follows:

$$
\begin{aligned}
& \text { Net_Migrasi } i_{t}=\alpha_{1}+\beta_{1} \text { Unemployment_rate }_{t-1}+\beta_{2} \text { GDP } / \text { Cap }_{t-1}+\varepsilon_{t} \\
& \text { Unemployment_Rate }_{t}=\alpha_{1}+\beta_{1} \text { Net }- \text { Migrasi }_{t-1}+\beta_{2} \text { GDP } / \text { Cap }_{t-1}+\varepsilon_{t} \\
& \text { GDP } / \text { Cap }_{t}=\alpha_{1}+\beta_{1} \text { Net }- \text { Migrasi }_{t-1}+\beta_{2} \text { Unemployment }_{-} \text {Rate }_{t-1}+\varepsilon_{t}
\end{aligned}
$$

Those are the VAR model transformation that the model will be dynamic by adding lag with the lag 1 assumption before applying optimum lag test.

\section{RESULTS AND DISCUSSION}

This study used two data analysis methods to achieve 2 different objectives. First, VAR was used to see the variable response when other variables experienced a change conducted through IRF test. In the VAR test, there were several pre-estimation tests consisted of data stationarity test (unit root), co-integration test, and optimum lag test. Then, after that, IRF test was conducted to see the variable response. The result of data stationarity test on the variable of net migration, unemployment rate, and income per capita were shown below.

Table 1. Data stationarity test result (Unit root test)

\begin{tabular}{lrrr}
\hline Variable & Level & First Difference & Second Difference \\
\hline Net_Migrasi & 0,4661 & $0,0001^{*}$ & 0,0000 \\
Unemployment & 0,5216 & $0,0163^{*}$ & 0,0000 \\
GDP/Cap & 0,9824 & $0,0062^{*}$ & 0,0000 \\
\hline
\end{tabular}

Source: Data, processed: 2019

Table 1 showed that the data on variables used in this study model were stationary at the first difference level. The result was confirmed by the probability value at the first difference level in each variable which was less than alpha 5\%. On the Net_migrasi variable, the probability value was 0,0001 . Meanwhile, in the unemployment and GDP/Cap as the proxy of income per capita had the probability value of 0.0163 and 0.0062. Next, to see if there was a co-integration and long-term relationship within the model used, a co-integration test was conducted through Johansen Test.

Table 2. Co-integration test result with Johansen Test

\begin{tabular}{lrrr}
\hline & Critical Value & Trace Statistic & Description \\
\hline $1 \%$ & 35.45817 & 23.81486 & Not Co-integrated \\
$5 \%$ & 29.79707 & 23.81486 & Not Co-integrated \\
$10 \%$ & 27.06695 & 23.81486 & Not Co-integrated \\
\hline Source: Data, processed: 2019 & &
\end{tabular}

From the co-integration test result above, we can conclude that this study model 
did not have any long-term relationship with the variable used in the model. This was confirmed by comparing the critical value and statistics trace result from each alpha level. At alpha 1\%, the statistics trace value was smaller than the critical value $(23.81846<35.45817)$. At alpha $5 \%$, the statistics trace result was smaller than the critical value $(23.81486<29.79707)$. Alpha $10 \%$ also showed the similar result where statistics trace was smaller than the critical value $(23.81486<27.06695)$. Thus, the result indicated that there was not any co-integration within the model. Then, the optimum lag result could be seen below.

Table 3. Optimum lag test

\begin{tabular}{cc}
\hline Lag & AIC \\
\hline 0 & 49.07349 \\
1 & $42.54803^{*}$ \\
2 & 42.77889 \\
\hline
\end{tabular}

Source: Data, processed: 2019

The optimum lag in this study was at lag 1 with the AIC value of 42.54803 . This result supported the result of co-integration test where it concluded that there was not any long-term relationship within the model. Logically, if we connected this result with the case in this study, it means the society directly responded the dynamics of unemployment and income per capita by quickly deciding whether or not they need to emigrate which later will cause migration flow is dominated with negative value. The net_migrasi which showed negative number also means that there is more emigration than immigration. Thus, more local people emigrate abroad than those migrant people come to Indonesia. This was the response to the increasing unemployment rate and low income per capita that they emigrate abroad to gain a better welfare.

Several pre-estimation tests above were conducted that we could obtain the result and decide if the model will continue through VAR estimation or VECM estimation. Based on the data stationarity test result which showed a stationary result at the first difference level and the co-integration test which showed that there was not any cointegration or long-term relationship within the model used, then, we can continue to VAR test. IRF was an important test in VAR where we could see the response of each variable when there was a change at the other variables.

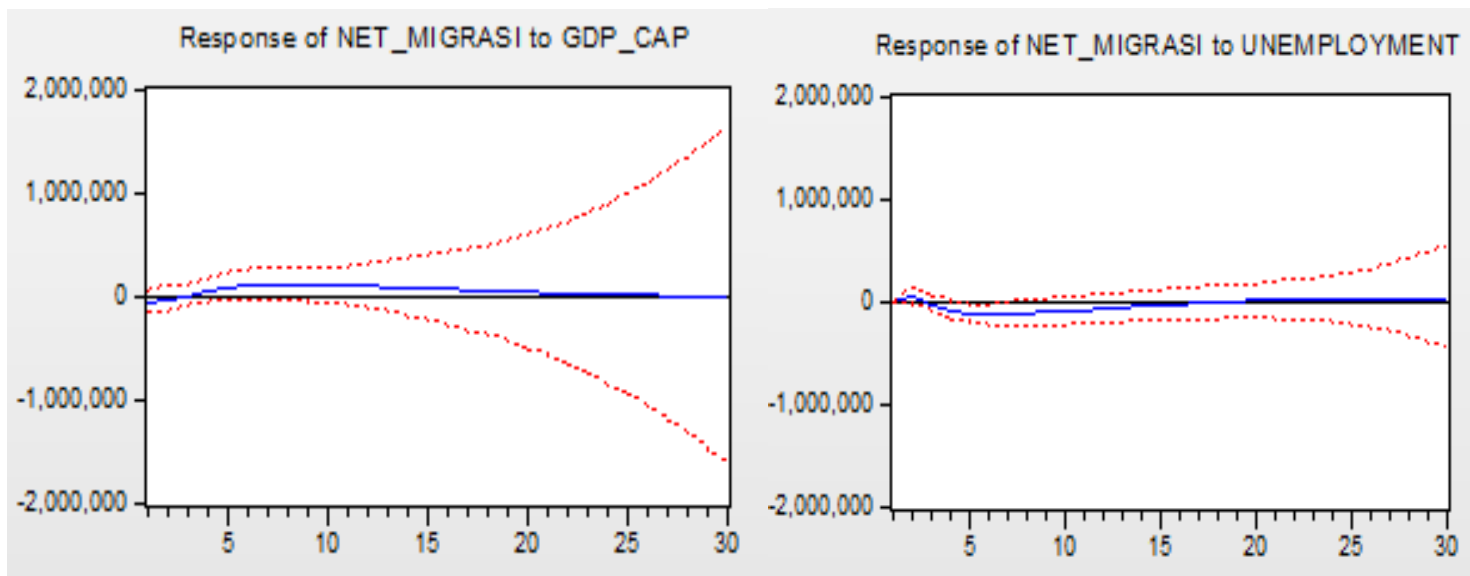

Figure 1. Impulse response function

Source: Data, processed: 2019 
The response showed among variables when other variables experienced a shock can be seen on Figure 1. Net_migrasi showed a relatively high response when there was a shock on GDP per capita as the proxy of income and unemployment dynamics. The change of GDP per capita was greatly responded by net_migrasi in Indonesia as shown in Figure 1 that started from period 15 until 30, the response was considered as very high.

As a matter of fact, based on the data from World Bank, net migration in Indonesia showed negative number. It means there are so many Indonesian societies who conduct international emigration due to the higher income per capita, especially in the past 30 years. However, the great amount of emigration also provides a forward looking to the welfare improvement of the emigrant obtained from a higher income.

In the relation to the international financial condition, high emigration rate will impact the remittance sent for their family. This will positively impact the cash flow as well as increasing the foreign exchange of the country. In terms of number, Indonesian emigrants will tend to be higher since Indonesia is placed as fourth world's most populous country. Still, in terms of population ratio, the number of Indonesian emigrants may not be that large. In 2010 until 2015, Indonesian emigrants were noted at 1,15 million people (BPS, 2015). The number will be increasing years after along with the higher global economy integration which will also increase the emigration flow intensity. The emigration phenomenon does not happen only for seeking a job, but also some of them are studying abroad. Still, workers dominate the emigration for improving their welfare.

Besides, the unemployment dynamics also gave a relatively high response for the migration flow though it was not as high as the response for GDP per capita. This was showed by the relatively stable response of migration flow on the unemployment dynamics at the beginning of the period until period 20 and then the response was increasing until period 30. This means the migration flow, which was dominated by emigration, in the Indonesian international migration data was not that high due to the unemployment dynamics. Because the unemployment rate showed a relatively good trend which declined the unemployment rate into 5,01\% on February 2019 (BPS, 2019). Basically, the migration flow was mostly caused by economic factors. Still, there were some caused by natural disaster which urges the people to migrate to the other countries. Besides, education became a reason for students to emigrate.

The result of OLS estimation to see the effect of dependent variable on the independent variable can be seen on the Table 4.

Table 4. OLS estimation result

\begin{tabular}{lrrr}
\hline Variable & Coefficient & Probability & Description \\
\hline GDP/Cap & $-175,0696$ & 0,0003 & Negative Significant \\
Unemployment & 25276,61 & 0,0001 & Positive Significant \\
\hline
\end{tabular}

Source: Data, processed: 2019

The OLS estimation result confirmed that the migration flow in Indonesia was significantly influenced by the dynamics of income per capita and unemployment rate. This was shown at Table 4 along with the probability value and coefficient found from the estimation result. Income per capita had a negative significant effect on the 
migration flow with the coefficient value of 175.0696 and probability value of 0.0003 which was less than alpha 5\%. This result means any decline of income per capita by 1 unit will increase the migration flow which is symbolized as more deficits on net migration number (minus) will increase migration by the amount of the coefficient value. More minus on the net migration data indicates more Indonesian people emigrate abroad with various reasons.

However, several reports confirmed that most of Indonesian emigrants were seeking for jobs to gain a better welfare and a higher income. In the other hand, when the income per capita increased by 1 unit, the migration flow decreased by the amount of the coefficient value. In this case, the migration flow decrease could be in the form of decreased deficit number on net migration. This will increase the income and decrease the emigration rate which later it will turn out attracting immigrant to work in Indonesia as the global economy liberalization expanding.

Meanwhile, the unemployment rate reflected from the unemployment rate data showed a positive significant effect on the data of migration flow in Indonesia. This was confirmed by the coefficient value of 25276.61 and the probability value of 00001 which was less than alpha 5\%. This means an increase on unemployment rate by 1 unit will increase the migration flow by the amount of the coefficient value. Meanwhile, a decrease on unemployment rate by 1 unit will decrease migration flow by the amount of the coefficient value. In this phenomenon, it means the increasing unemployment rate in Indonesia will cause an increasing migration flow. Based on the current data, Indonesia faces a deficit which implies that we have more emigrants than immigrants. Several studies showed that the imbalance amount of job vacancy and labors causes unemployment. This became the push factor for the worker to emigrate in hope of having greater opportunity to work and gaining higher income to improve their life.

Several studies supported this result such as Ramirez et al. (2014) which showed that the correlation between unemployment and emigration are stronger from time to time. While in the relation of income, it stated that income was closely related to emigration which tends to increase when the income declines. This was reflected through the crisis phenomena which destroyed the economy that many workers decided to emigrate to the other region or even abroad. This was in line with the result stated unemployment has a positive impact on migration flow, especially emigration.

Government integrations in managing the migration flow were shown at, for example, policies and effort to legally protect the migrants. In Indonesia, the majority of emigrants migrate abroad so that various government efforts contribute to protecting emigrants through the establishment of the National Agency for the Placement and Protection of Indonesian Workers who are established in various regions with control centers in the National BPNP2TKI. This institution aims to facilitate and formulate policies in a coordinated and integrated manner for Indonesian workers who are abroad as well as monitoring and releasing policies (Sugandi and Heryadi, 2017).

In recent years Indonesia has become the country with the largest number of emigrants in the Asian region and the majority aims to find more decent jobs (Sugandi and Heryadi, 2017). This is also motivated by the population of Indonesia, the majority of which comprise a population of productive age greater than other ASEAN countries. Immigration and Emigration will tend to show its dominance when the economic 
conditions are up and down. In an up condition or the economy is in good condition, it will tend to lead to greater immigration and vice versa, when the economy is in a down or sluggish condition it will tend to result in increased emigration with the aim of seeking better welfare.

Migration driven by economic factors in the long run will have an impact on the welfare of emigrant families. Remittances as cash inflows from remittances from emigrants to home countries can be used more productively so that they can have an impact on increasing productivity. In addition, when the remittance fund flow is used for investment in human resources such as education and health for his family, in the long run it can also contribute to improving the quality of human capital. In addition, the flow of outgoing migration is also an effort for Indonesian workers to escape the phenomenon of unemployment. As well as one of the government's efforts to distribute labor in countries that have collaborated with the government in terms of employment that is managed legally and officially through established institutions.

\section{CONCLUSIONS AND RECOMMENDATIONS}

\section{Conclusions}

In the phenomenon of migration flow in Indonesia in the short term is still very dominant influenced by economic drivers which are confirmed by the results of cointegration that indicate no co-integration or long-term relationship to migration flow, unemployment rate and per capita income. Meanwhile, the response through the IRF test that migration flow in Indonesia is shown by net migration data with a deficit value (dominated by emigration than immigration) is very vulnerable to dynamics in the unemployment rate and per capita income over the last 30 years.

The results of the OLS estimation also show the results that per capita income has a significant negative effect on net migration in Indonesia. These results confirm that this migration flow depends on conditions on the dynamics of per capita income. If income increases, it will reduce emigration and can actually increase immigration so that the net migration rate becomes positive or surplus. Meanwhile, if per capita income decreases it will result in increased emigration. Other results indicate that the unemployment rate will have a significant positive effect on the flow of migration that is deficit means that when the unemployment rate increases it will have an effect on increasing emigration resulting in a negative or deficit net migration.

\section{Recommendations}

Many policies have been carried out to respond to the phenomenon of international migration both through strengthening cooperative relations with destination countries in an effort to strengthen guarantees and protections for emigrants and immigrants. Other follow-up that might be done by the government is more on the results or output especially those produced by emigrants. The output can be in the form of foreign exchange reserves and remittances to be managed more productively especially as an effort to increase human resources which in the long run will have a positive impact on development while increasing the competitiveness of Indonesian workers. So that government integration can be through increased productivity and 
proper allocation of foreign exchange reserves and remittances for more productive investments so that in the long run it can also improve the welfare of the community especially for the emigrants and families concerned.

\section{REFERENCES}

Badan Pusat Statistik. (2019). Berita Resmi Statistik: Keadaan Ketenagakerjaan Indonesia Februari 2019. Jakarta: BPS

Badan Pusat Statistik. (2015). International Migration Statistics in Indonesia. Jakarta: BPS

Badan Pusat Statistik. (2015). Kajian Migrasi Internasional Hasil Sensus Penduduk 2010 dan Survei Penduduk Antar Sensus. Jakarta : BPS

Cattaneo, C. (2008). The Determinants of Actual Migration and the Role of Wages and Unemployment in Albania: an Empirical Analysis. The European Journal of Comparative Economics, 5 (1), 3-32.

Cushing, B. \& Poot, J. (2004). Crossing boundaries and borders: Regional science advances in migration modelling. Papers in Regional Science, 83, 317-338. http://dx.doi.org/10.1007/s10110-003-0188-5

Engle, R.F. \& Granger, C.W.J., (1987). Co-Integration and Error Correction: Representation, Estimation, and Testing. Econometrica, 55(2), 251-276.

Heid, B., \& Larch, M. (2011). Migration, Trade and Unemployment. Ifo Institute, Ifo Working Paper, No. 115.

Latif, E. (2015). The relationship between immigration and unemployment: Panel data evidence from Canada. Economic Modelling 50 (2015) 162-167

Martinoia, M. (2011). European Integration, Labour Market Dynamics and Migration Flows. The European Journal of Comparative Economics, 8(1), 97-127.

Mihi-Ramirez, A. \& Kumpikaite, V. (2013). The European migration flow in a context of deterioration of economic factors. The case of Spain. Economics and management, 18(3), 479-484.

Mihi-Ramirez, A. (2013). The 180 degree turn about economic migrants flow. An analysis of the case of Spain and Latin America. Public Policy and Administration, 12(1), 9-21.

Monseny, J. J. (2014). The effects of unemployment protection on migration in lagging regions. Journal of Urban Economics 83 (2014) 73-86

Ramírez, A.M., Rudžionisb, A., \& Kumpikaitè, V. (2014). European economic migration flow, earnings and unemployment in decade of 2000. Procedia - Social and Behavioral Sciences, 110, $122-129$

Sugandi, Y. S. \& Heryadi, D. (2017). Indonesia's Cross Border Migration Policy (A Case Study of Indonesian Migrant Workers at Malaysia). Jurnal Wacana Kinerja 20(2)

Timorria, I.M. (2018). Indonesia Tekan Pentingnya Peran Migran Internasional dalam Pembangunan. Available

at: https://kabar24.bisnis.com/read/20181211/19/868227/indonesia-tekankanpentingnya-peran-migran-internasional-dalam-pembangunan

Vojtovich, S. (2013). The Impact of Emigration on Unemployment in Slovakia. Inzinerine Ekonomika-Engineering Economics, 24(3), 207-216. 
IOM-UN Migration. World Migration Report. (2018). International Organization for Migration.

Zimmermam, K. F. (1996). European Migration: Push and Pull. International Regional Science Review, 19(1\&2), 95-128.

(C) 2020 by the authors. Licensee JPPD, Indonesia. This article is an open-access article distributed under the terms and conditions of the Creative Commons Attribution (CC BY) license (http://creativecommons.org/licenses/by/4.0/). 